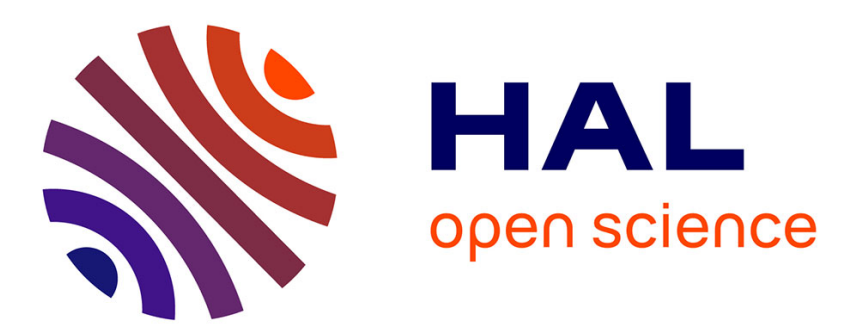

\title{
First E.S.R. observation of injected electrons trapped in electrets
}

\author{
Michel Legrand, G. Dreyfus, J. Lewiner
}

\section{To cite this version:}

Michel Legrand, G. Dreyfus, J. Lewiner. First E.S.R. observation of injected electrons trapped in electrets. Journal de Physique Lettres, 1977, 38 (21), pp.439-440. 10.1051/jphyslet:019770038021043900 . jpa-00231415

\section{HAL Id: jpa-00231415 https://hal.science/jpa-00231415}

Submitted on 1 Jan 1977

HAL is a multi-disciplinary open access archive for the deposit and dissemination of scientific research documents, whether they are published or not. The documents may come from teaching and research institutions in France or abroad, or from public or private research centers.
L'archive ouverte pluridisciplinaire HAL, est destinée au dépôt et à la diffusion de documents scientifiques de niveau recherche, publiés ou non, émanant des établissements d'enseignement et de recherche français ou étrangers, des laboratoires publics ou privés. 


\title{
FIRST E.S.R. OBSERVATION OF INJECTED ELECTRONS TRAPPED IN ELECTRETS
}

\author{
M. LEGRAND, G. DREYFUS and J. LEWINER \\ Laboratoire d'Electricité Générale, Ecole Supérieure de Physique et de Chimie de la Ville de Paris, \\ 10, rue Vauquelin, 75005 Paris, France
}

(Reçu le 20 juillet 1977, accepté le 27 septembre 1977)

\begin{abstract}
Résumé. - La résonance paramagnétique électronique (R.P.E.) a été utilisée pour l'étude des phénomènes liés à la formation d'électrets par bombardement électronique. Deux types de phénomènes ont été mis en évidence : la formation de radicaux par destruction de liaisons et le piégeage d'électrons injectés. Le premier de ces phénomènes a déjà été étudié; en revanche, les électrons piégés n'avaient jamais été mis en évidence autrement que par les méthodes classiques d'électrométrie. Le présent article porte sur la mise en évidence de la raie denR.P.E. des électrons injectés ; ceci semble constituer la première approche de l'effet électret au niveau microscopique.

Abstract. - The present paper reports an investigation of electron bombarded electrets by electron spin resonance (E.S.R.). It is shown that two phenomena occur : radicals are formed by the breaking of bonds during the irradiation, and injected electrons are trapped. Although the first phenomenon is well known, the latter had never been observed except by conventional electrometer measurements. We report and discuss the observation of the E.S.R. line of trapped electrons; this seems to be the first microscopic investigation of the electret effect.
\end{abstract}

The phenomena associated with the long-term polarization of insulating materials are of great complexity. Among the problems still unsolved are those related to the space charge build-up and the transport properties.

For many years, the investigations of electrets have been carried out with purely macroscopic methods (charge or potential measurements); they would lead to the knowledge of the overall charge, but gave no indications of the microscopic processes involved in the trapping of charges. In order to get a better insight into these phenomena, thermally stimulated processes have been investigated (thermally stimulated currents [1] or thermoluminescence); these methods provide values of the activation energies or trap depths which can either be used as a phenomenological characterization of the materials, or be incorporated in a model of conduction and trapping in the materials under investigation. Photon stimulated current spectroscopy [2] and infrared spectroscopy [3] have provided alternate data. In order to obtain direct information on the phenomena involved in the injection and trapping of charges, we have used electron spin resonance (E.S.R.) spectroscopy.

In this paper we report what we believe to be the first observation of the E.S.R. line of trapped electrons in a polymer electret.

1. Experimental. - The samples used in this study were $10 \mu$ thick isotactic polypropylene films, irra- diated with 5 to $15 \mathrm{kV}$ electrons. The charge density injected into the sample was measured in situ immediately after the bombardment or after longer periods of time. The effective surface charge density was of the order of $10^{-8} \mathrm{cb} / \mathrm{cm}^{2}$. Such a density gives a number of electrons in the samples of the order of $10^{13}$.

A standard E.S.R. spectrometer was used, operating around $9.14 \mathrm{GHz}$. The incident power could be varied from 0.1 to $200 \mathrm{~mW}$. A Varian standard was used for calibration purposes.

2. Observed data. - Immediately after the irradiation a very broad line due to the paramagnetic radicals formed in the sample is observed $[4,5]$; a very similar line is obtained after irradiation of a sample by $X$ rays and its intensity can be equal to that obtained by electron irradiation. This line is easily eliminated by annealing the sample for half an hour at $100^{\circ} \mathrm{C}$. After this annealing process has been carried out, another E.S.R. line can be observed, which was masked by the strong radical line. Figure 1 shows both the line (a) observed after irradiation (radical line) and the Lorentzian spectrum $(b)$ recorded after annealing. We attribute the latter to the excess electrons trapped in the polymer during the bombardment. This hypothesis is supported by the following experimental observations.

1) The $g$ factor of this line is very close to 2 : $g=2.004 \pm 0.001$. This suggests that it is due either 


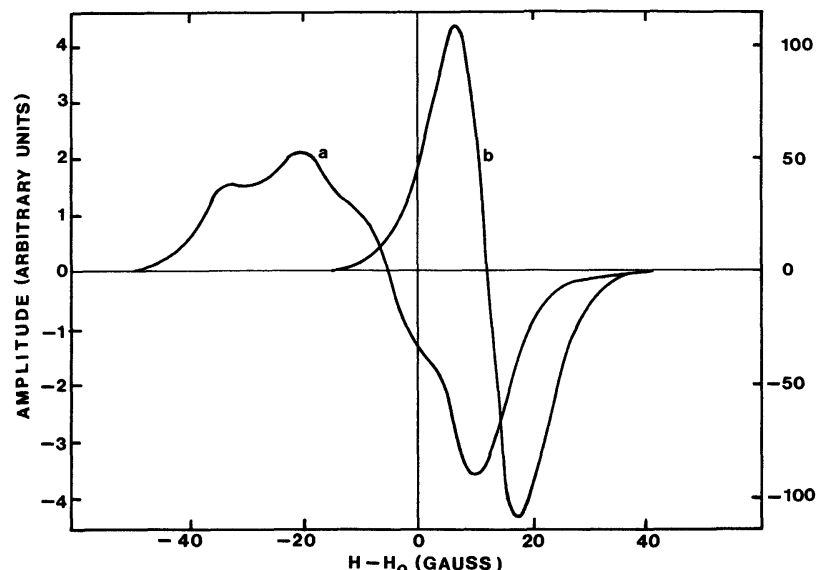

FIG. 1. - a) E.S.R. line due to radicals produced during the electron injection (with reference to right-hand scale). b) E.S.R. line observed after annealing at $100^{\circ} \mathrm{C}$ for half an hour (with reference to left-hand scale). The same units are used on both scales.

to free radicals or to trapped electrons. Free radicals, however, are known to be very sensitive to temperature and to recombine at temperatures of the order of $100{ }^{\circ} \mathrm{C}$ or less [6].

2) This line does not appear in the case of $X$ ray irradiated samples. This shows that the observed line is not due to free radicals or to paramagnetic species arising during the annealing of the sample.

3) The spectrum is very narrow. The peak to peak line width is 11 gauss.

4) The line undergoes saturation at room temperature for powers of the order of $1 \mathrm{~mW}$ as is shown on figure 2. It should be noted that this value greatly exceeds the saturation power of the stabilized electrons due to $\gamma$ irradiation in saturated hydrocarbons, which is close to $10 \mu \mathrm{W}$ [7]. It is coherent with the fact that the excess electrons injected during the bombardment are much more strongly trapped in electrets than the excited electrons due to the irradiation of hydrocarbons; the latter can be observed at liquid nitrogen temperature only.

5) The number of spins producing this line has been measured by comparison with a standard sample. It is of the order of $10^{13}$, which agrees with the number of trapped charges measured by standard electrometric measurements.

6) There is a direct correlation between the net excess charge present in the sample and the intensity

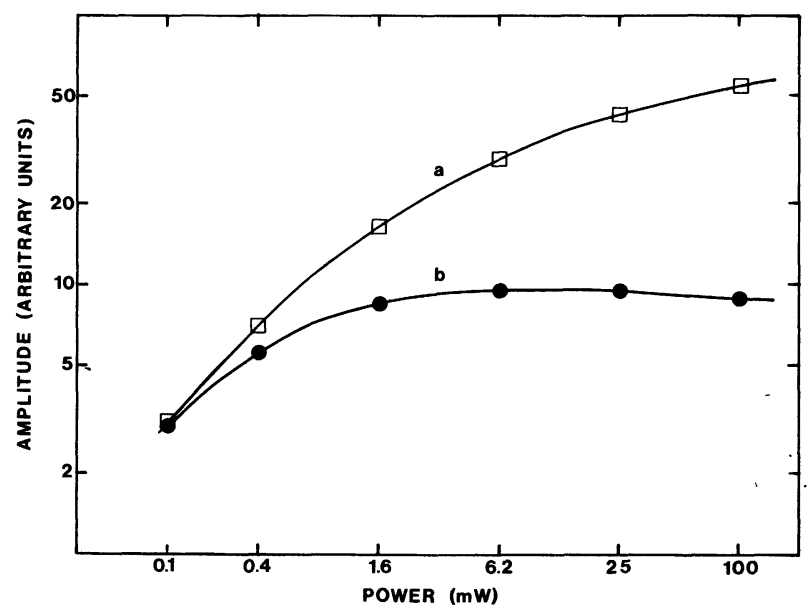

Fig. 2. - Comparison of line amplitudes as a function of incident power. a) Varian standard ; $b$ ) Electret.

of the E.S.R. line. This was demonstrated by the following experiment : electrets were formed by electron injection, heated to $120^{\circ} \mathrm{C}$ and the E.S.R. line was observed ; the process of heating and recording the spectrum was subsequently repeated. When the heating was performed without contacting electrodes, the E.S.R. line remained unchanged. On the other hand, however, the E.S.R. line was found to decrease by $50 \%$ in 50 minutes when contacting electrodes were used; the decay was approximately linear in the time range investigated (10 minutes to 40 minutes).

These two types of behaviour can be interpreted as follows : when contacting electrodes are used, the internal field of the electret is driving the thermally mobilized electrons toward the polymer-metal interface where they are released into the metal. On the contrary, when this condition is not satisfied, the electrons are thermally excited and are driven by the internal fields and the diffusion forces into an equilibrium distribution. They are kept in the sample.

3. Conclusion. - In this paper we have reported the observation of electron spin resonance lines produced by the excess charge trapped in a polypropylene electret. This technique is the first to allow direct microscopic observation of these charges. It should prove a very powerful tool for the study of transport and charge storage phenomena in polymer dielectrics.

\section{References}

[1] Van Turnhout, J., Thermally Stimulated Discharge of Polymer Electrets (Elsevier) 1975.

[2] BrodribB, J. D., O'Colmain, D. and Hughes, D. M., J. Phys. D 9 (1976) 253.

[3] Hartman, K. and O'Brien, R. N., Electrets, Charge Storage and Transport in Dielectrics (M. M. Perlman, Editor) 1973, p. 444

[4] Dreyfus, G., Thèse de Doctorat ès Sciences, Paris (1976).
[5] Durand, P. and Fournié, R., Bull. Dir. Et. Rech. EDF B 1 (1972) 15.

[6] See for instance :

Bass, A. M. and BroIDA, H. P., Formation and Trapping of free radicals (Academic Press) 1960.

[7] Keyser, R. M. and Williams, F., J. Phys. Chem. 73 (1969) 1629. 